\title{
A Dilemma of Proximal Tubule in An Infant: Hypophosphatemia and Hypourisemia Without Hypokalemia and Acidosis: Questions
}

\author{
Eren Soyaltın ${ }^{1}$ (D) $\cdot$ Belde Kasap Demir ${ }^{1,2} \cdot$ Gökçen Erfidan $^{1} \cdot$ Seçil Arslansoyu Çamlar ${ }^{1} \cdot$ Demet Alaygut $^{1}$. \\ Fatma Mutlubaş ${ }^{1}$
}

Received: 26 August 2019 / Revised: 26 August 2019 / Accepted: 6 September 2019/Published online: 3 January 2019

(C) IPNA 2020

\section{Case summary}

A 22-month girl was referred to our clinic upon detection of glycosuria and proteinuria in urine analysis. Her medical history was uneventful except a history of immature teratoma diagnosed on the $20^{\text {th }}$ postnatal day. Physical examination revealed low body height and weight for her age $[9,7 \mathrm{~kg}$ (-1,46 SDS); $76 \mathrm{~cm}(-2,79 \mathrm{p})]$ with normal motor and mental development. A surgical scar tissue was observed on umbilicus. No other pathology was detected. Laboratory investigations showed hypourisemia $[1.7 \mathrm{mg} / \mathrm{dL}$ (normal: 2 - 5.5 $\mathrm{mg} / \mathrm{dL}$ )] and hypophosphatemia [3.9 mg/dL (normal: $4-7$ $\mathrm{mg} / \mathrm{dL}$ )]. Serum glucose, hepatic and pancreatic enzymes, bilirubin levels, renal functional tests and other electrolytes including sodium, calcium, chloride, potassium and magnesium were within normal range. The blood gases analyze were normal ( $\mathrm{Ph}$ : 7,43 mmHg, HCO3: $21.9 \mathrm{mmol} / \mathrm{L}$, BEecf: $1.0 \mathrm{mmol} / \mathrm{L})$. The total urine analysis revealed +2 proteinuria, +3 glycosuria. The urine density was 1015 and $\mathrm{pH}$ was 5.5. In spot urine analysis for evaluation of tubular functions were: FENa: \% 1, FEK: \% $20(\uparrow)$, TPR: \% $62(\downarrow)$, FEUa: $\% 57(\uparrow)$ and urine calcium-creatinine ratio: $0,15 \mathrm{mg} /$ $\mathrm{mg}$. Urine protein-creatinine ratio was $4 \mathrm{mg} / \mathrm{mg}$. Urine protein electrophoresis was consistent with tubular proteinuria and urine $\beta 2$ globulin level was high $[0.69 \mathrm{gr} / \mathrm{L}$ normal: $0.00-0.14)$ ]. Ophthalmological examination was totally normal.

\section{Questions}

1. How do you define the laboratory findings in this patient?

2. What would be the underlying causes leading to this problem in children?

3. What should be questioned in this patient and what would be the most likely causative factor?
Eren Soyaltın

erensoyaltin@hotmail.com

1 Department of Pediatrics, Division of Nephrology, University of Health Sciences Izmir Tepecik Training and Research Hospital, İzmir, Turkey

2 Department of Pediatrics, Division of Nephrology, Izmir Katip Çelebi University Faculty of Medicine, İzmir, Turkey 